\title{
Individual Factors Influencing Career Growth Prospects in Contexts of Radical Organizational Changes
}

\author{
David E. Okurame ${ }^{1}$ \\ ${ }^{1}$ Department of Psychology, University of Ibadan, Nigeria \\ Correspondence: David E. Okurame, Department of Psychology, University of Ibadan, Nigeria. E-mail: \\ daveokurame@yahoo.com
}

Received: July 16, 2014

Accepted: July 29, 2014

Online Published: September 25, 2014

doi:10.5539/ibr.v7n10p74

URL: http://dx.doi.org/10.5539/ibr.v7n10p74

\begin{abstract}
This study examined the influence of individual factors (demographic variables, self-efficacy beliefs and personal growth initiative) on career growth prospects within the context of radical organizational changes such as downsizing, mergers and acquisition. Data were collected using the questionnaire method from 199 employees in branches of a commercial bank located in a major city in South-Western Nigeria. Results of the simple multiple regression analysis showed that educational attainment $(\beta=-.15, p<.05)$, tenure in the banking sector $(\beta=-.41, \mathrm{p}<.01)$, basic monthly income $(\beta=.46, \mathrm{p}<.001)$ and job status $(\beta=.34, \mathrm{p}<.01)$ are significant demographic factors in career growth prospects. The analysis of covariance which controlled for covariates revealed significant differences in the career growth prospects of employees with low levels of self-efficacy and those with high levels - in favor of the latter. In contrast, high or low levels of personal growth initiative resulted in comparable levels of career growth prospects. Self-efficacy beliefs and personal growth initiative interacted significantly to affect career growth prospect such that greater levels of career growth prospect was expressed irrespective of whether an employee is high or low on personal growth initiative when self-efficacy belief is high. Implications of findings are discussed.
\end{abstract}

Keywords: career, banking sector, personal growth initiative, self-efficacy beliefs, downsizing, acquisition, demographic data, Nigeria

\section{Introduction}

Employees often hope to grow in their profession and to achieve a distinguished career (Okurame \& Balogun, 2005). The probability that this will come to fruition is the underlying thrust of career growth prospect. Defined as the chances of getting promoted and obtaining career development experiences, career growth prospect is arguably an essential source of motivated work behavior (Weer, 2006; Okurame, 20012a). The mere expectation of moving up an organization's hierarchy through promotion and obtaining beneficial career development experiences increases an employee's effort and motivates a strong involvement in organizational and career activities (Mowday, Porter \& Steers, 1982; Eisenberger, Lieberman \& Williams, 2003). Indeed, empirical investigations have shown that such optimism is accompanied by job effectiveness (Avey, Nimnicht \& Pigeon, 2010), increased job attendance (Eisenberger, Huntington, Hutchison \& Sowa, 1986), a greater willingness to remain with an organization, and pro-social actions from employees (Meyer \& Allen, 1984; Brief \& Motowidlo, 1986; O'Reilly \& Chatman, 1986; Okurame, 2012a). Again, when employees have favorable perceptions of prospects for career growth, they tend to be more willing to go along with work changes and strive to stay up-to-date on their work activities even when it is not particularly convenient for them. The proven importance of career growth prospect, therefore, demands that adequate empirical attention be paid to it.

Further justifications for the present study is provided in the next section, followed by a literature review that examines the potential link of individual factors (demographic variables, self-efficacy beliefs and personal growth initiatives) to career growth prospects. The subsequent two sections explain the data generation process and the results of data analyses respectively. The last three sections discuss findings in relation to the literature, draw conclusions with practical implications of findings and highlight study limitations respectively.

\subsection{Justification for the Study}

Given the significance of career growth prospects for employee performance, many organizations have made 
efforts to be responsive to the career needs of employees through education, mentoring, training and upward promotion for deserving employees. It is expected that this would increase the possibility of career growth and encourage employees to go the extra mile in the discharge of their assigned duties. However, career growth has become a major challenge for employees in modern organizations due to drastic organizational changes. Given the global economic climate, organizations are reorganizing staff and culture, collapsing organizational layers, downsizing, and engaging in mergers or acquisition to enhance solvency and remain competitive. Unfortunately, this trend tends to reduce opportunities for hierarchical promotion among surviving employees (Heslin, 2005) and creates uncertainties that have heightened the need to focus empirical attention on career growth and development (Whiston \& Blustein, 2010).

In the Nigerian environment, the phenomenon is clearly evident in the banking sector and has raised concerns for obvious reasons. Employees in the Nigerian banking sector have great expectations of career growth in their organizations but prevailing circumstances in the sector make meeting such expectations a challenge (Okurame, 2012a). In the prevailing circumstances, bank employees need to work even harder to merit being put up for the limited career growth openings. Although, the literature (Brutus, Ruderman, Ohlott, \& McCauley, 2000) suggests that these changes may offer opportunities for development experiences and content advancement, limited opportunities for hierarchical advancement which necessarily occur (Heslin, 2005) may hinder favorable perceptions of career growth prospects. Indeed, empirical investigation reveals that promotions and upward movement through an organization's hierarchy is a valued index of career growth and a successful career in the Nigerian context (Okurame, in press). A promotion within an organization's hierarchy generally represents status and increased responsibility, reflects a recognition of an employee's worth in the organization, a better pay, and creates opportunities for even further advancement (London \& Stumpf, 1983). It is logical, therefore, to expect that having to work even harder and to wait until there is an opening for upward movement (which may never come in years) may foster perceptions of unmet career growth expectations in the sector.

The expectancy approach to employee efficiency suggests that bank employees will constantly be encouraged to exert effort to perform well in needed organizational functions when there is an expectation that this will always be followed by valued career outcomes (Okurame \& Balogun, 2005). Therefore, unmet expectations of an upward movement in a career within an organization would be expected to bring harrowing experiences to employees with attendant negative consequences for motivation and performance in organizational roles (Ivancevich \& Matteson, 1980; Okurame \& Balogun, 2005). Consequently, an empirical investigation of factors that may enhance or inhibit career growth prospect is important and necessary to enhance its role in the effectiveness of the Nigerian banking sector. Although speculation about the helpful influence of individual factors is making the rounds, these are largely based on logical reasons rather than empirical. Thus, the present study examined the influence of individual factors (demographic variables, self-efficacy beliefs and personal growth initiative) on career growth prospects to fill the identified gap in literature. Gaining a better understanding of the ways in which these variables impact career growth prospect has practical importance as this will offer organizations an insight into policies and programs that will increase prospects of career growth among their employees. This is important and necessary especially for organizations that consider meeting the career growth needs of their employees a strategic factor in attracting and retaining talented staff. Equally important, the findings will offer employees who are committed to a career in the banking sector, valuable insights into how prospects for career growth can be enhanced.

\section{Literature Review}

\subsection{Demographic Variables and Career Growth Prospects}

Although, no research has investigated the direct influence of demographic variables on career growth prospects in the literature, considerable research evidence suggests that demographic variables are valuable factors in career attitude and growth (e.g. Powell \& Butterfield, 1994; Okurame \& Balogun, 2005; Sullivan \& Arthur, 2006; Grimland, Vigoda-Gadot \& Baruch, 2012; Okurame, 2012b). For example, gender differences have been linked to career attitudes. While men tend to be more motivated by promotion, women build careers that are relational based (Inceoglu, Segers, Bartram \& Vloeberghs, 2008). Besides, the complexity of career for men and women differ (Huang, El-Khouri, Johaneson, Lindroth \& Sverko, 2007). Compared to women, men are more under social pressure to earn an income which is enhanced by hierarchical promotion (Richter, 2011).

Findings in the literature showed that age as well may account for differences in career growth prospects as it influences the extent to which an employee may be able to resist social pressure regarding the usefulness of hierarchical promotion (Sullivan, Martin, Carden \& Mainiero, 2003). The literature suggests that an employee's career attitude is less guided by social pressure about what to do as he or she gets older (Inceoglu et al., 2008; 
cited in Segers, Inceoglu. Vloeberghs, Bartram, \& Hendericks, 2008). Conversely, however, research findings show that employees with higher levels of education, status and work experience undertake more development activities and pay greater importance to hierarchical promotion than their counterparts at lower levels (Cheramie, Sturman \& Walsh, 2007; cited in Segers, Inceoglu, Vloeberghs, Bartram \& Hendericks, 2008). It is logical, therefore, to expect that the demographic data of employees would influence their perceptions of career growth prospects.

\subsection{Self-Efficacy Beliefs and Career Growth Prospect}

Self-efficacy belief is a construct within the social cognitive theory which reflects an individual's judgment of his or her capability to do well in a range of situations or tasks (Bandura, 1978; Ashford \& LeCroy, 2010; Lunenburg, 2011). It is not necessarily based on actual ability, but on what is believed by an individual. Indeed, actual ability and beliefs about such abilities scarcely tally as people with competencies often express low self-efficacy beliefs such that it limits what they do with their skills (Pajares, 2002). Social cognitive theory argues that individuals are capable of reflecting on previous actions and utilize the outcomes of such reflections as a guide for determining future behavior especially in challenging moments (Stajkovic \& Luthans, 1998; Bandura, 2001; Nevid, 2009). Unless an individual believes he or she can accomplish a desired outcome, sufficient inspiration to act or persevere will be lacking (Bandura, 2001). Self-efficacy or the belief in one's ability to attain a goal determines the actions that an individual takes and the extent to which they pursue such goals, and their outcome expectations (Bandura, 1997; Turan, Valcke, Aper, Koole \& Derese, 2013). Consequently, the potential impact of self-efficacy beliefs on career growth or its prospect stems from its influence on an individual's achievement striving and persistence in the face of career challenges (Bandura, 1982; Lent \& Hackett, 1987; Gist \& Mitchell, 1992; Stajkofic \& Luthans, 1998; Ballout, 2009; Oni, 2013; Wright, Jenkins-Guarnieri \& Murdock, 2013).

Without a doubt, if a worker has good self-efficacy beliefs, this can lead to high aspirations and a stronger commitment to set goals in the face of challenges (Bandura, 1997; Wu, 2002; Okurame, 2006). Findings of studies have underscored the importance of efficacy beliefs in career-related performance (Lent \& Hackett, 1987; Lent, Brown, Talleyrand, McPartland, Davis, Chopra, Alexander, Suthakaran \& Chai, 2002). A belief in self-efficacy enhances perceived personal control over career growth opportunities (Gist \& Mitchell, 1992; Schwarzer \& Scholz, 2000; Malherbe, Stell \& Theron, 2003), improves the individual's ability to cope with pressure and challenging tasks (Williams \& Willians, 2010), and positively impacts on self-sufficiency (Saks, 1995), job planning and team work performance (Chen, Webber, Bliese, Mathieu, Payne, Born \& Zaccaro, 2002; Fort, Jacquet \& Leroy, 2011). Conversely, low self-efficacy increases pessimism about an individual's ability to accomplish an endeavor, leading to lower utilization of skills and a lack of effort (Bandura \& Cervone, 1983; Schwarzer \& Scholz, 2000). Therefore, it is logical to expect that bank employees with high levels of self-efficacy beliefs will have high expectations about performing well, making them approach career issues and career growth opportunities with greater determination. On the contrary, bank employees who feel that their effort cannot lead to desired career outcome, will be less willing to engage in career related behavior, and this should in turn, diminish their feelings of prospects for career growth. Consequently, it is expected that high levels of self-efficacy will result in greater levels of career growth prospects compared to low levels of self-efficacy beliefs.

\subsection{Personal Growth Initiative (PGI) and Career Growth Prospects (CGP)}

Personal growth initiative is another variable which has been canvassed as an important factor in career growth prospects in the Nigerian banking sector. Defined as the intentional and active involvement of an individual in the process of personal growth (Robitschek, 1998), it is theoretically assumed to contain both cognitive and behavioral components (Robitschek, 2003). Personal growth initiative involves a readiness for change, an ability to be strategic in an effort to attain goals, an ability to identify and access resources, intentional follow-up behavior and a pre-occupation with self-improvement (Robitschek, Ashton, Spering, Murray, Geiger, Martinez \& Shotts, 2010). Although the construct which has its roots in positive psychology is at its infancy; it is emerging as a useful approach for helping human development, prosperity and personal fulfillment through self-determination. Positive personal growth initiative spurs confidence in the ability to handle challenging life and career events and to take advantage of growth opportunities (Robitschek, Ashton, Martinez, Murrey \& Shotts, 2009; Ayub \& Igbal, 2012; Sharma \& Rani, 2013; Yakunina, Weigold \& Weigold, 2013). It makes employees adopt a proactive approach to work which is characterized by a long-term goal-oriented focus and going beyond job requirements even in the face of obstacles (Robitschek \& Cook, 1999).

People with a high personal growth initiative actively seek out self-change and self-growth experiences, setting 
explicit growth goals and foreseeing success in uncertain situations (Sharma \& Rani, 2013). Setting explicit personal growth goals makes it possible for individuals to direct their attention and effort towards relevant goal attainment activities and optimal functioning (Karakowsky \& Mann, 2008; Weigold, Porfeli, \& Weigold, 2013). Often, they seek and acquire knowledge of the process of personal growth in their fields by keeping abreast of procedures and specific things needing change (Sharma \& Rani, 2013). Findings show that individuals with high personal growth initiative scores report greater problem solving activities and hope in doing well, especially in tasks that demand awareness and intentionality (Whittaker \& Robitschek, 2001; Shorey, Little, Snyder, Kluck \& Robitschek, 2007). Given that individuals with high scores on personal growth initiative tend to seek growth experiences and have a high level of future-oriented growth, it is logical to expect that they would report greater levels of career growth prospects. Consequently, this study proposes that a bank employee's personal growth initiative would significantly distinguish him or her on career growth prospects.

\subsection{Interaction Effects of Self-Efficacy Beliefs and PGI on CGP}

The possibility that efficacy beliefs and personal growth initiative may interact to significantly affect career growth prospects seems logical and robust. Arguably, self-efficacy beliefs may be an important factor in whether or not an individual engages in the self-determination tendencies of personal growth initiative, because a good level of self-efficacy provides the motivation for making personal growth plans and the effort to attain them. In a reverse manner, a tendency for personal growth initiative may also advance self-efficacy beliefs in ways that positively affect career growth prospects. Personal growth initiative is a self-change process that enhances the perception of an individual's skill and their ability to be strategic and successful (Robitschek et al., 2009). Self-efficacy beliefs and personal growth initiative are both future-related constructs and may combine in useful ways to affect expectations or prospects of career growth. Indeed, empirical evidence (i.e. Sharma \& Rani, 2013) of the relationship between these variables emerged recently in a study among postgraduate students. Consequently, this largely untested assumption was examined in the present study.

\subsection{Study Hypotheses}

In view of the theoretical arguments, empirical findings and logical expectations discussed in the preceding paragraphs, the present study formulated and tested the following hypotheses: Hypothesis 1: Demographic data of respondents will have significant independent and joint influence on career growth prospects. Hypothesis 2: Bank employees with high scores on self-efficacy beliefs would report greater levels of career growth prospect compared to their counterparts with low scores on self-efficacy. Hypothesis 3: Bank employees with high scores on personal growth initiative would report greater levels of career growth prospect compared to their counterparts with low scores on personal growth initiative. Hypothesis 4: There would be significant interaction effects of self-efficacy beliefs and personal growth initiative on career growth prospect.

\section{Method}

\subsection{Setting}

The study was carried out among employees in branches of a bank in a major city in south-western Nigeria. The organization is a commercial bank which has been involved in restructuring, downsizing and acquisition. The career growth procedure of the bank gives preference to employees who meet the organization's key performance indices. Ultimately, therefore, employees in the organization take responsibility for their career growth.

\subsection{Participants}

Data for the study were collected from respondents who were selected through the purposive sampling method. They were employees who worked in the branches of the sampled bank. They were available at the time of survey and were willing to participate in the study. The respondents comprised 98 (49.2\%) male and 101 (50.8\%) female employees whose ages ranged from 18 to 50 , with a mean age of 30.49 years ( $\mathrm{SD}=5.54$ ). Participants were $155(77.9 \%)$ junior, $30(15.1 \%)$ middle level and $14(7.0 \%)$ management staff. The majority of the respondents were married $(51.8 \%, \mathrm{n}=103)-48.2$ percent were single. The average participant had worked for 4.86 years $(\mathrm{SD}=4.25)$ in the banking sector and 2.96 years $(\mathrm{SD}=2.21)$ in their current organization. Their highest educational qualification varied thus: $29(14.6 \%)$ had ordinary national diploma, $49(24.6 \%)$ held higher national diplomas, $97(48.7 \%)$ held first degrees and $24(12.1 \%)$ had postgraduate qualifications.

\subsection{Measures}

Data were collected through a questionnaire containing measures of demographic, self-efficacy beliefs and personal growth initiative that served as independent variables, and the dependent variable, career growth prospects. 


\subsubsection{Demographic Data}

Demographic data included sex, age, marital status and highest educational attainment, tenure in the banking sector and with current organization, basic monthly income and job status. A single item was used in assessing each of these variables. Age, tenure in the banking sector, and tenure with current organization were measured as continuous variables. Other demographic data were dichotomized thus; sex (coded $1=$ male; $2=$ female), marital status (coded $1=$ single; $2=$ married), highest educational attainment (coded $1=$ ordinary diploma; $2=$ higher national diploma; 3 = first degree; $4=$ postgraduate degree), basic monthly income level (coded $1=$ up to 50, 000 naira; $2=50,001$ to 100,$000 ; 3=100,001$ and above), job status (coded $1=$ junior officer; $2=$ middle level officer; 3 = management staff).

\subsubsection{Self-Efficacy Beliefs}

This was assessed by a 10-item English version of the general self-efficacy beliefs scale developed by Schwarzer and Jerusalem (2000). The scale items evaluate the extent to which a respondent feels he or she can cope with adversities, perform difficult tasks and obtain desired outcomes. Sample items include "Thanks to my resourcefulness, I know how to handle unforeseen events", "I can always manage to solve difficult problems if I try hard enough" and "It is easy for me to stick to my aim and accomplish my goals." The authors reported coefficient alpha reliability estimates of between .75 and .90 for the scale in several studies. The scale has been used among Nigerian samples in a previous study (i.e., Okurame, 2006). In the current study, the coefficient alpha for the scale was .80. Participants were required to indicate the extent to which scale items reflect their person on a 4-point scale ranging from not at all true (1) to exactly true (4). High scores indicate high levels of general self-efficacy beliefs, while low scores indicate low levels of efficacy beliefs. Respondents with scores at and below the sample mean score in the present study were categorized as low, while their counterparts with scores above the sample mean were categorized as high.

\subsubsection{Personal Growth Initiative}

This variable was measured by a 9-item personal growth initiative scale developed by Robitschek, (1998). The scale measures a respondent's 'desire to be involved in changing and developing him/herself, and to actively and intentionally engage in the process of personal growth (Robitschek, 1998). Sample items include "I know what I need to do to get started toward reaching my goals", "I have a plan for making my life more balanced," and "if I want to change something in my life, I initiate the transition process." The scale is a reliable measure of personal growth initiative which has demonstrated considerable construct validity (Robitschek, 1998, 1999; Martin, 2009). Evidence of scale validity was derived in this study from factor analyses results which revealed significant factor loadings of at least .64 and a .58 lowest item-total correlation. In the current study, the coefficient alpha for the scale was .79. Participants were required to specify the extent to which they agree or disagree with scale items on a 6-point scale ranging from definitely disagree (1) to definitely agree (6). High scores indicate high levels of personal growth initiative, while low scores indicate low personal growth initiative. Employees with scores at and below the mean score in the present sample were categorized as low, while their counterparts with scores above the sample mean score were categorized as high.

\subsubsection{Career Growth Prospects}

This was assessed using an 11-item scale modified from Weer (2006). The items measured an employee's perception of the likelihood that he or she would move up his or her organization's hierarchy through promotion and beneficial career development experiences. Sample items include: "I have reached a point in my career where it is unlikely that I will move higher in this organization", "It is likely that my job in this organization will constantly challenge me" and "In this organization, the opportunities for promotion are limited for me". The scale has been used in a previous study (i.e., Okurame, 2012a) of bank employees in Nigeria. Validation evidence for the scale in the current study was found in significant item-total correlations and factor analysis results which revealed that career growth prospect is a single construct. In the current study, the coefficient alpha for the scale was .76. Respondents expressed the extent to which they agree or disagree with scale items on a 5 -point scale ranging from 1 (strongly disagree) to 5 (strongly agree). High scores signify high levels of career growth prospects, while low scores signify low levels of career growth prospects.

\subsection{Procedure}

Data were collected through the questionnaire method during office hours in branches of the sampled banking organization. Permission to carry out the study in the selected banks was obtained from the head of the different units where questionnaires were administered. Potential participants were handed study questionnaires during regular working hours with the assistance of contact persons in each of the branches that served as a setting for 
the study. Employees were informed about the aim of the research and were encouraged to take part in the study. Respondents were told that participation in the study was not compulsory and that they could inform the researchers of their intention to withdraw from the study at any point in the research. They were assured that information supplied would be held in confidence and that the present research was purely for academic purposes. A total of 230 questionnaires with an attached consent page were handed to interested employees. Respondents were requested to fill the questionnaire at their leisure and submit the completed questionnaire to their organization's contact person for subsequent collection. Two hundred and twelve questionnaires were received at the close of survey. However, questionnaires that had missing data were eliminated, resulting in 199 questionnaires with complete data for analysis. This represents an 86.5 percent response rate.

\section{Results}

The present study utilized the simple multiple regression analysis and the analysis of covariance to explore the linkage among study variables. Hypothesis 1 , which predicted that demographic data of respondents will have significant independent and joint influence on career growth prospects, was examined using the simple multiple regression analysis. The demographic variables that were introduced into the regression equation include: sex, age, marital status, highest educational qualification, and tenure in the banking sector, tenure in current organization, basic monthly income and job status. Table 1 presents the results of this analysis.

Table 1. Results of multiple regression analysis predicting career growth prospects

\begin{tabular}{lcccc}
\hline Variable & $\beta$ & $\mathrm{t}$ & $\mathrm{R}^{2}$ & $\mathrm{~F}$ \\
\hline Sex & -.02 & -0.227 & $.23^{* * *}$ & $7.159^{* * *}$ \\
Age & .01 & 0.110 & \\
Marital status & -.02 & -0.189 & \\
Education & $-.15^{*}$ & $-2.010^{*}$ & \\
Banking sector tenure & $-.41^{* *}$ & $-2.628^{* *}$ & \\
Organi zation tenure & .16 & 1.603 & \\
Monthly basic income & $46^{* * *}$ & $4.895^{* * *}$ & \\
Job status & $34^{* * *}$ & $3.459^{* * *}$ & \\
\hline
\end{tabular}

$* *=\mathrm{p}<.01 . * * *=\mathrm{p}<.001$.

Results in Table 1 revealed that all of the demographic variables jointly accounted for a significant variance in career growth prospect $\left(\mathrm{R}^{2}=.23, \mathrm{p}<.001\right)$. However, the independent influence of the variables on career growth prospects differed, indicating that hypothesis 1 was partly supported. As shown in Table 1, of all the demographic data examined in the study, educational attainment, tenure in the banking sector, basic monthly income and job status were the only variables with significant independent relationships with career growth prospects. Educational attainment $(\beta=-.15, \mathrm{p}<.05)$ and tenure in the banking sector $(\beta=-.41, \mathrm{p}<.01)$ had significant negative relationships with career growth prospect, indicating that the higher the number of years an employee has spent in the banking sector and the higher their educational attainment, the lower their reported level of career growth prospects, and vice versa. On the other hand, basic monthly income $(\beta=.46, \mathrm{p}<.001)$ and job status $(\beta=.34, \mathrm{p}<.001)$ were significantly and positively related to career growth prospects. Because basic monthly income (up to 50,000, between 50,001 and 100,000, and above 100,000) and job status (junior, middle and management staff) were categorized into three levels in the study, further statistical analysis was carried out to examine career growth prospects across the three levels of each variable. This analysis involved the one way analysis of variance, which enabled the simultaneous consideration of the three groups on the dependent variable while avoiding probability pyramiding, and the protracted t-test multiple comparison test. Results of the analysis (not presented in table) showed that the main influence of basic monthly income was supported, $\mathrm{F}(2,196)=$ $19.519, \mathrm{p}<.001$. The mean career growth prospects reported by employees with income levels of up to 50,000 $(M=38.7)$ and those with income levels of between 50,001 and 100,000 $(M=40.6)$ were comparable. However, both were significantly different from the level of career growth prospects expressed by employees with income levels of 100,001 and above $(M=44.4)$. Thus, the significantly higher level of career growth prospect reported by employees with income levels of 100,001 and above is the source of the significant influence of basic monthly income. Similarly, results of the one way analysis of variance (not presented in table) showed that the 
main influence of job status was supported, $\mathrm{F}(2,196)=10.683, \mathrm{p}<.001$. The mean career growth prospects reported by junior employees $(M=40.4)$ were significantly different from those reported by middle level $(\mathrm{M}=$ 44.3) as well as management officers $(\mathrm{M}=46.2)$ whose scores were comparable. Thus, the significantly lower level of career growth prospects reported by junior employees is the source of the significant influence of job status.

The significant relationships of educational attainment, tenure in the banking sector, basic monthly income and job status with career growth prospects necessitated the consideration of these variables as covariates in the examination of hypotheses 2,3 , and 4 . To reduce error variance, the demographic variables which have significant relationships with the dependent variable of study were selected as covariates for analysis (Cohen \& Cohen, 1983). However, basic monthly income $(r=0.68, \mathrm{p}<.001)$ and job status $(r=0.74, \mathrm{p}<.001)$ were highly correlated with tenure in the banking sector. Consequently, basic monthly income and job status were removed from analyses to maintain power (Bordens \& Abbott, 1988). Therefore, hypotheses 2, 3, and 4, which borders on the main and interaction effects of self-efficacy beliefs and personal growth initiative on career growth prospect, were tested using the analysis of covariance to enable the control of educational attainment and bank sector tenure which eventually served as covariates in the study.

Table 2. ANCOVA results for the main and interaction effects of self-efficacy beliefs and personal growth initiative on career growth prospects

\begin{tabular}{lrrrr}
\hline Source & SS & df & MS & F \\
\hline Educational attainment & 10.03 & 1 & 10.03 & 0.313 \\
Banking sector tenure & 247.733 & 1 & 247.733 & $7.725^{* *}$ \\
Self-efficacy beliefs (SEB) & 684.872 & 1 & 684.872 & $21.450^{* * *}$ \\
Personal growth initiative (PGI) & 115.672 & 1 & 115.672 & 3.607 \\
SEB x PGI & 143.951 & 1 & 143.951 & $4.489^{*}$ \\
Error & 6189.108 & 193 & 32.068 & \\
Total & 348678 & 199 & & \\
\hline$* *=\mathrm{p}<.01 . * * *=\mathrm{p}<.001$. & & & &
\end{tabular}

$*=\mathrm{p}<.05 . * *=\mathrm{p}<.01 . * * *=\mathrm{p}<.001$.

Hypothesis 2 predicted that employees who score high on self-efficacy beliefs will report a significantly greater level of career growth prospects compared to their counterparts who score low on self-efficacy beliefs. The results presented in Table 2 show that the main effects of self-efficacy beliefs on career growth prospects was significant, $\mathrm{F}(1,193)=21.450, \mathrm{p}<.001$. A comparison of mean scores revealed that employees who are high on self-efficacy beliefs $(M=43.2)$ reported greater levels of career growth prospects compared to their counterparts with low personal growth initiative $(M=39.4)$, hence, hypothesis 2 was supported.

Hypothesis 3 predicted that employees who are high on personal growth initiative will report significantly greater levels of career growth prospects compared to their counterparts who are low on personal growth initiative. Table 2 shows that the main effects of personal growth initiative on career growth prospects was not significant $(\mathrm{F}(1,193)=3.607, \mathrm{p} \mathrm{ns})$, indicating that the mean career growth prospect scores of employees who are high on personal growth initiative $(\mathrm{M}=42.1)$ are comparable to that of employees who are low on personal growth initiative $(M=40.5)$, hence hypothesis 3 was not supported.

Hypothesis 4 predicted that self-efficacy beliefs and personal growth initiative would interact significantly to influence career growth prospects. The results in Table 2 show that the interaction effect of self-efficacy and personal growth initiative on career growth prospects was significant, $F(1,193)=4.489, p<.05$. Hence, hypothesis 4 was supported. The significant interaction of self-efficacy beliefs and personal growth initiative yielded four groups of respondents. These include employees who are low on both self-efficacy beliefs and personal growth initiative $(n=48)$, those who are high on both self-efficacy beliefs and personal growth initiative $(n=65)$, those who are low on self-efficacy beliefs but high on personal growth initiative $(n=44)$, and employees who are high on self-efficacy beliefs but low on personal growth initiative $(n=42)$. Results of protracted t-test multiple comparison post hoc analysis of mean scores on career growth prospects of the four groups are presented in Table 3. 
Table 3. Protracted multiple comparisons for interaction effects of SEB and PGI on CGP

\begin{tabular}{|c|c|c|c|c|c|c|c|}
\hline Interacting Cells & 1 & 2 & 3 & 4 & $\mathrm{~N}$ & M & S.D \\
\hline Low SEB/low PGI & - & $-2.9^{* *}$ & $-5.5^{* * *}$ & $4.7^{* * *}$ & 48 & 37.8 & 6.38 \\
\hline Low SEB/high PGI & & - & $-1.9^{*}$ & $-1.8^{*}$ & 44 & 41.1 & 5.5 \\
\hline High SEB/low PGI & & & - & 0.2 & 42 & 43.3 & 5.04 \\
\hline High SEB/high PGI & & & & - & 65 & 43.1 & 5.85 \\
\hline
\end{tabular}

SEB $=$ Self-efficacy beliefs. PGI $=$ Personal growth initiative.

$\mathrm{CGP}=$ Career growth prospect. $*=\mathrm{p}<.05 . * *=\mathrm{p}<.01 . * * *=\mathrm{p}<.001$.

Table 3 reveals that the mean score of employees who are low on both self-efficacy and personal growth initiative is significantly different from the mean scores of all other groups. The low self-efficacy beliefs - high personal growth initiative group was significantly different from the high self-efficacy beliefs - low personal growth initiative group as well as the high self-efficacy beliefs - high personal growth initiative. The level of career growth prospects reported by the high self-efficacy - low personal growth initiative group were comparable with that reported by the high self-efficacy beliefs - high personal growth initiative group. This pattern of interaction is presented in figure 1.

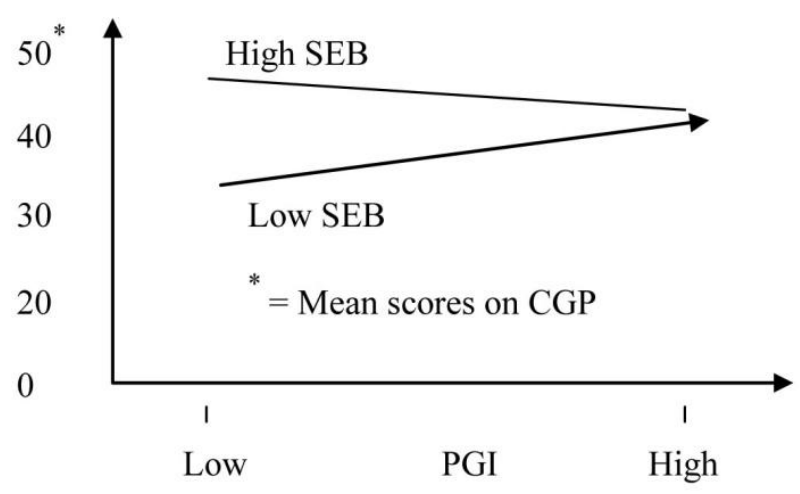

Figure 1. Interaction effects of SEB and PGI on CGP

Figure 1 shows that greater levels of career growth prospect are expressed irrespective of whether an employee is high or low on personal growth initiative when self-efficacy belief is high. As shown in figure 1, the least level of career growth prospect is reported by employees when their levels of self-efficacy belief and personal growth initiative are both low.

\section{Discussion}

The study investigated the role of demographic variables and the influence of self-efficacy beliefs and personal growth initiative (individual factors) on career growth prospect in the Nigerian banking sector. Findings of the study are partly in line with postulations in the extant literature about how these variables relate to career growth prospects. The study found educational attainment, tenure in the banking sector, basic monthly income and job status to be relevant demographic factors in career growth prospects. It also established a significant main effect of self-efficacy belief as well as a significant interaction effect of efficacy beliefs and personal growth initiative on career growth prospects. Study findings set the empirical foundation for the theory that employee demographic data, efficacy beliefs and personal growth initiative are useful factors in career growth prospects.

The first hypothesis of the study examined the differences in career growth prospects that may result from a respondent's demographic data such as sex, age, marital status, highest educational attainment, tenure in the banking sector, current organizational tenure, and income and job status. Although, all demographic factors acting together accounted for a significant variance in career growth prospects, findings show that highest educational attainment, tenure in the banking sector, basic monthly income and job status were the only variables with a significant independent relationship with career growth prospects. The non-significant relationship of age, sex and marital status with career growth prospects implies that young and old, male and female as well as 
married and single employees reported comparable levels of career growth prospects. This finding particularly contradicts the arguments and findings of previous studies (e.g. Sullivan et al., 2003; Huang et al., 2007; Inceoglu et al., 2008; cited in Segers et al., 2008; Richter, 2011) that age and gender are significant factors in career attitudes. While education and bank sector tenure were negatively related to career growth prospects, the relationship of basic monthly income and job status with career growth prospects were positive.

The negative relationship between bank sector tenure and career growth prospects implies that the longer the tenure of an employee in the banking sector and the more educated they are, the lower their reported level of career growth prospects, and vice versa. This represents an unexpected result when compared with the arguments of researchers (e.g. Cheramie et al., 2007: cited in Segers et al., 2008) that high levels of career experience and educational attainment necessarily spur development activities that enhance actual and favorable perception of growth prospects. An appropriate conclusion in the present study would therefore be that bank employees who have spent fewer years in the sector and who are comparatively less educated are at an advantage in respect to favorable perception of career growth. A probable explanation for the current finding may be that employees with less experience in the sector and those with comparatively lower educational attainment are more expectant of career growth and/or receive more career growth support than their opposite counterparts, making them more positive about career growth prospects. Another plausible reason would be that there are greater opportunities for low tenure bank employees and employees with lower educational attainment than for their opposite counterparts. Alternatively, it may be that low tenure bank employees and employees with low educational attainment feel a greater need to seek career growth and this, probably, enhances their perception of career growth prospects.

The positive relationships of basic monthly income and job status with career growth prospects imply that higher income levels and elevated job status foster a more favorable perception of career growth prospects among bank employees. This position is given credence by the results of the one-way analysis of variance and post hoc analysis that compared career growth prospects across the three levels of the two demographic variables. Unlike the results regarding tenure and educational attainment, the nature of the relationship between job status and career growth prospects is consistent with the conclusion of Cheramie et al. (2007) that higher status increases the importance of hierarchical promotion and fosters a more favorable perception of growth opportunities. Consequently, a likely explanation for this finding may be that higher levels of income and job status enhances the perception of further growth opportunities thereby augmenting perceived career growth prospects above that of their counterparts with lower income and job status. Alternatively, it could be argued that higher income and job status make bank employees feel a greater need to seek career growth opportunities in ways that ultimately enhance career growth prospects. Otherwise, a possible explanation for the findings would be that bank employees with higher levels of income and job status value career growth in their sector so much so that it provides them sufficient inspiration to report its prospects with greater enthusiasm compared to employees with low income and job status.

Results indicate a significant main effect of self-efficacy beliefs on career growth prospects. Mean comparison revealed that the level of career growth prospects reported by employees with high self-efficacy was greater than that reported by those who were low on self-efficacy. This implies that the higher a bank employee's self-efficacy, the better their perception of career growth prospects. This finding is in line with theoretical arguments and results of studies in the extant self-efficacy literature. For example, the current finding supports the postulation of Bandura (1997) that belief in one's ability to attain a goal determines achievement striving and leads to high expectations of success in a given task. It is also consistent with findings of previous studies that self-efficacy beliefs enhance favorable perceptions of control over career growth opportunities (Gist \& Mitchell, 1992; Schwarzer \& Scholz, 2000; Malherbe, Stell \& Theron, 2003) and encourages commitment when faced with task challenges (Okurame, 2006). Consequently, and on the basis of the social cognitive theory, one probable explanation for the finding is that favorable levels of self-efficacy enhance a bank employee's beliefs about being able to control career growth opportunities, causing them to routinely report favorable levels of career growth prospects. Alternatively, it may be that high self-efficacy beliefs make it possible for a bank employee to engage in actual career growth activities within their organization, such that this adequately fosters favorable perceptions of prospects for career growth.

That personal growth initiative did not have a significant main effect on career growth prospect implies that it does not appreciably enhance or diminish a bank employee's level of career growth prospect. Consequently, the level of career growth prospects reported by employees who scored high on personal growth initiative and those who scored low were comparable. This is an unexpected finding because it contradicts the position of the literature on the influence of personal growth initiative on career growth prospect. Previous studies (e.g. 
Robitschek et al, 2010; Robitschek, Ashton, Spering, Geiger, Byers, Schotts \& Thoen, 2012) have reported that personal growth initiative spurs readiness for change in the face of challenges; enhances strategy in effort and intentional follow-up behavior aimed at taking advantage of growth opportunities and fulfilling growth goals. The current findings, therefore, suggest that high or low levels of personal growth initiative do not exclude a bank employee from the career challenges of their sector. One probable explanation for the non-significant main effect in the current finding is that personal growth initiative, on its own, may not be useful in revealing differences in the career growth prospects of bank employees.

The finding that career growth prospects is significantly influenced by the interaction effects of self-efficacy beliefs and personal growth initiative, implies that different levels of the two variables have implications for prospective career growth. Given that the main effect of personal growth initiative on career growth prospect is not significant, the interaction effect also implies that this variable is only relevant within the context of an employee's level of self-efficacy. The results of multiple comparison of interacting cells showed that the weakest level of career growth prospect was obtained when self-efficacy and personal growth initiative are both low while greater levels were obtainable irrespective of whether a bank employee is high or low on personal growth initiative only when self-efficacy belief is high. The implication of this finding is that low levels of self-efficacy and personal growth initiative inhibit elevated levels of career growth prospects and combining these variables to attain superior levels of career growth prospects is possible only when self-efficacy is high.

\section{Conclusions and Practical Implications of Findings}

The findings of this study are of particular practical relevance to organizations, especially the Nigerian banking sector, that desire to be responsive to the career needs of employees despite inhibiting organizational changes. Results suggest that career growth prospect is amenable through intervention, making it possible for the management to influence perception of career growth prospects within their organization. The findings of this study will go a long way in making it possible for both management and employees to facilitate prospects for career growth. Findings show that the management will need to pay adequate attention to demographic factors such as educational attainment, tenure in the banking sector, basic monthly income and job status which were found to be significant variables in prospects for career growth. Higher monthly income and job status makes it more likely for some employees to have expectations of further career growth, signifying that low levels predispose employees to an unfavorable perception of career growth. In contrast, higher educational attainment and longer tenure in the banking sector were found to inhibit favorable levels of career growth prospects. Interventions should therefore be styled to address the concerns of this category of employees.

Findings show that higher levels of self-efficacy are associated with higher levels of career growth prospects. Management intervention should therefore aim at enhancing the self-efficacy beliefs of employees in order to foster prospects for career growth. This would also make it possible to tap into the positive combined effects of self-efficacy and personal growth initiative as the study's findings showed that superior levels of career growth prospects are possible in such circumstance.

\section{Limitations of Study}

Though this study extends our understanding of the influence of self-efficacy beliefs and personal growth initiative on career growth prospects, caution is required in the interpretation of results for a number of reasons. First, data for the study are subject to the usual limitations of a survey research, as they were obtained from self-report instruments. This call for caution as under or over reporting cannot be totally ruled out despite the use of psychometrically sound measures. Second, the study is an exploratory research. Therefore, data from employees in a single organization in the Nigerian banking sector may not typify organizations in general. This calls for caution in generalizing study findings to include employees in the banking sector in general or in other organizational contexts.

\section{References}

Ashford, J. B., \& LeCroy, C. W. (2010). Human behavior in the social environment: A multidimensional perspective $(4$ th ed.). Belmont, CA: Wadsworth, Cengage Learning. Retrieved from http://books.google.com/books?id=R8-HitN5Jp0C

Avey, J. B., Nimnicht, J. L., \& Pigeon, N. G. (2010). Two field studies examining the association between positive psychological capital and employee performance. Leadership and Organisational Development Journal, 31(5), 384-401. http://dx.doi.org/10.1108/01437731011056425

Ayub, N., \& Iqbal, S. (2012). The relationship between personal growth initiatives, psychological well-being and psychological distress among adolescents. Journal of Teaching and Education, 1(6), 101-107. 
Ballout, H. I. (2009). Career commitment and career success: moderating role of self-efficacy. Career Development International, 14(7), 655-670. http://dx.doi.org/10.1108/13620430911005708

Bandura, A., \& Cervone, D. (1983). Self-evaluative and self-efficacy mechanisms governing the motivational effects of goal systems. Journal of Personality and Social Psychology, 45, 1017-1028. http://dx.doi.org/10.1037/0022-3514.45.5.1017

Bandura, A. (1978). Reflections on self-efficacy. Advances in Behavioral Research and Therapy, 1(4), 237-269. http://dx.doi.org/10.1016/0146-6402(78)90012-7

Bandura, A. (1982). Self-efficacy mechanism in human agency. American Psychologist, 37(2), 122-147. http://dx.doi.org/10.1037/0003-066X.37.2.122

Bandura, A. (1997). Self-efficacy: The exercise of control. New York, NY: Freeman.

Bandura, A. (2001). Social cognitive theory: an agentive perspective. A Review of Psychology, 52, 1-26. http://dx.doi.org/10.1146/annurev.psych.52.1.1

Bordens, K. S., \& Abbott, B. B. (1988). Research Design and Methods: A Process Approach. Mountain View, CA: Mayfield Publishing Company.

Brief, A. P., \& Motowidlo, S. J. (1986). Pro-social organisational behaviours. Academy of Management Review, $10,710-725$.

Brutus, S., Ruderman, M., Ohlott, P., \& McCauley, C. (2000). Developing from job experiences: the role of organisation-based self-esteem. Human Resource Development Quarterly, 11, 367-380. http://dx.doi.org/10.1002/1532-1096(200024)11:4<367::AID-HRDQ4>3.0.CO;2-6

Chen, G., Webber, S. S., Bliese, P. D., Mathieu, J. E., Payne, S. C., Born, D. H., \& Zaccaro, S. J. (2002). Simultaneous examination of the antecedents and consequences of efficacy beliefs at multiple levels of analysis. Human Performance, 15, 381-409. http://dx.doi.org/10.1207/S15327043HUP1504_05

Cheramie, R. A., Sturman, M. C., \& Walsh, K. (2007). Executive career management: Switching organizations and the boundaryless career. Journal of Vocational Behaviour, 71, 359-374. http://dx.doi.org/10.1016/j.jvb.2007.09.002

Cohen, J., \& Cohen, P. (1983). Applied multiple regression/correlation analysis for the behavioural sciences. Hillsdale, NJ: Erlbaum.

Eisenberger N. I., Lieberman, M. D., \& Williams, K. D. (2003). Does rejection hurt? An fMRI study of social exclusion. Science, 302, 290-292. http://dx.doi.org/10.1126/science.1089134

Eisenberger, R., Huntington, R., Hutchison, S., \& Sowa, D. (1986). Perceived organisational support. Journal of Applied Psychology, 75, 51-59. http://dx.doi.org/10.1037/0021-9010.75.1.51

Fort, I., Jacquet, F., \& Leroy, N. (2011). Self-efficacy, goals and job search behaviour. Career Development International, 16(5), 469-481. http://dx.doi.org/10.1108/13620431111168886

Gist, M. E., \& Mitchell, T. R. (1992). Self-efficacy: A theoretical analysis of its determinants and malleability. Academy of Management Review, 17, 183-211.

Grimland, S., Vigoda-Gadot, E., \& Baruch, Y. (2012). Career attitudes and success of managers: the impact of chance event, protean, and traditional careers. The International Journal of Human Resource Management, 23(6), 1074-1094. http://dx.doi.org/10.1080/09585192.2011.560884

Heslin, P. A. (2005). Conceptualizing and evaluating career success. Journal of Organizational Behavior, 26, 113-136. http://dx.doi.org/10.1002/job.270

Huang, Q., El-Khouri, B. M., Johansson, G., Lindroth, S., \& Sverke, M. (2007). Women's career patterns: A study of Swedish women born in the 1950s. Journal of Occupational and Organizational Psychology, 80, 387-412. http://dx.doi.org/10.1348/096317906X119738

Inceoglu, I., Segers, J., Bartram, D., \& Vloeberghs, D. (2008). Age differences in work motivation. Paper presented at the 23rd Annual Conference of the Society for Industrial and Organizational Psychology, San Francisco.

Ivancevich, J. M., \& Matteson, M. T. (1980). Stress and Work. Scott, Foresman and Co., Glenview, IL.

Karakowsky, L., \& Mann, S. L. (2008). Setting goals and taking ownership: Understanding the implications of participatively set goals from a causal attribution perspective. Journal of Leadership \& Organizational 
Studies, 14, 260-270. http://dx.doi.org/10.1177/1071791907308047

Lent, R. W., \& Hackett, G. (1987). Career Self-Efficacy: Empirical Status and Future Directions. Journal of Vocational Behavior, 30, 347-382. http://dx.doi.org/10.1016/0001-8791(87)90010-8

Lent, R. W., Brown, S. D., Talleyrand, R., McPartland, E. B., Davis, T., Chopra, S. B., Alexander, M. S., Suthakaran, V., \& Chai, C. M. (2002). Career choice barriers, supports, and coping strategies: College students' experiences. Journal of Vocational Behavior, 60, 61-72. http://dx.doi.org/10.1006/jvbe.2001.1814

London, M., \& Stumpf, S. (1983). Effects of candidate characteristics on management promotion decisions: an $\begin{array}{lllll}\text { experimental study. } & \text { Personnel 241-259. }\end{array}$ http://dx.doi.org/10.1111/j.1744-6570.1983.tb01435.x

Lunenburg, F. (2011). Self-efficacy in the workplace: implications for motivation and performance. International Journal of Management, Business, and Administration, 14(1).

Malherbe, D. G., Stell, H. R., \& Theron, W. H. (2003). The contribution of self-efficacy and outcome expectations in the prediction of exercise adherence. South African Journal for Research in Sport, Physical Education and Recreation, 25(1), 71-82. http://dx.doi.org/10.4314/sajrs.v25i1.25832

Martin, H. (2009). Personal growth initiative as a moderator of expressive writing tasks: test of a matching hypothesis. Master's Thesis, Faculty of the Graduate School of the University of Maryland, College Park.

Meyer, J. P., \& Allen, N. J. (1984). Testing the 'side-bet theory' of organisational commitment: some methodological considerations. Journal of Applied Psychology, 69, 372-378. http://dx.doi.org/10.1037/0021-9010.69.3.372

Mowday, R. T., Porter, 1. W., \& Steers, R. M. (1982). Employee-organisational linkages: The psychology of commitment, absenteeism, and turnover. New York, NY: Academic Press.

Nevid, J. S. (2009). Psychology: Concepts and applications (3rd ed.). Boston: Houghton Mifflin Company.

O'Reilly, C., \& Chatman, J. (1986). Organisational commitment and psychological attachment: The effects of compliance, identification, and internalization on pro-social behaviour. Journal of Applied Psychology, 71(3), 492-499. http://dx.doi.org/10.1037/0021-9010.71.3.492

Okurame, D. E., \& Balogun, S. K. (2005). Role of Informal Mentoring in the Career Success of First-line Bank Managers: a Nigerian case study. Career Development International, 10(6/7), 512-521. http://dx.doi.org/10.1108/13620430510620584

Okurame, D. E. (2006). Role of self-efficacy beliefs in goal commitment: a case study of the $20^{\text {th }}$ Nigerian university games chess event. South African Journal for Research in Sports, Physical Education and Recreation, 28(2), 113-120.

Okurame, D. E. (2012a). Impact of career growth prospects and formal mentoring on organisational citizenship behaviour. Leadership and Organisational Development Journal, 33(1), 66-85. http://dx.doi.org/10.1108/01437731211193124

Okurame, D. E. (2012b). Linking work-family conflict to career commitment: the moderating role of gender and mentoring. Journal of Career Development, 39(5), 423-442. http://dx.doi.org/10.1177/0894845310391903

Okurame, D. E. (In press). Perceptions of career success and new career orientation occurrence in the academia. Manuscript submitted for Publication.

Oni, S. (2013). Challenges and prospects in African education system. North America: Trafford Publishing.

Pajares, F. (2002). Overview of social cognitive theory and of self-efficacy. Retrieved from http://www.emory.edu/EDUCATION/mfp/eff.html

Powell, G. N., \& Butterfield, D. A. (1994). Investigating the glass ceiling phenomenon: an empirical study of actual promotions to top management. Academy of Management Journal, 37(1), 68-86. http://dx.doi.org/10.2307/256770

Richter, A. (2011). Job Insecurity and Its Consequences: Investigating Moderators, Mediators and Gender. (Doctoral dissertation, Stockholm University, Sweden). Retrieved from http://www.diva-portal.org/smash/get/diva2:453238/FULLTEXT01.pdf

Robitschek, C. (1998). Personal growth initiative: The construct and its measure. Measurement and Evaluation in Counselling and Development, 30, 183-198. 
Robitschek, C. (2003). Validity of Personal Growth Initiative Scale scores with a Mexican American College Student Population. Journal of Counseling Psychology, 50(4), 496-502. http://dx.doi.org/10.1037/0022-0167.50.4.496

Robitschek, C., \& Cook, S. W. (1999). The influence of personal growth initiative and coping styles on career exploration and vocational identity. Journal of Vocational Behaviour, 54, 127-141. http://dx.doi.org/10.1006/jvbe.1998.1650

Robitschek, C., Ashton, M. W., Spering, C. C., Geiger, N., Byers, D., Schotts, G. C., \& Thoen, M. A. (2012). Development and psychometric evaluation of the Personal Growth Initiative Scale-II. Journal of Counselling Psychology, 59, 274-287. http://dx.doi.org/10.1037/a0027310

Robitschek, C., Ashton, M. W., Spering, C. C., Murray, D. D., Geiger, A. N., Martinez, M., \& Shotts, G. C. (2010). Measuring Multidimensional Personal Growth Initiative: Development of the Personal Growth Initiative Scale - II. Manuscript submitted for publication.

Robitschek, C., Ashton, M. W., Spering, C. C.. Martinez, M., Shotts, G. C., \& Murray, D. (2009). Development of the Personal Growth Initiative Scale - II. Poster presented at the 2009 World Congress on Positive Psychology, Philadelphia, PA.

Saks, A. M. (1995). Longitudinal field investigation of the moderating and mediating effects of self-efficacy on the relationship between training and newcomer adjustment. Journal of Applied Psychology, 80, 211-225. http://dx.doi.org/10.1037/0021-9010.80.2.211

Schwarzer, R., \& Jerusalem, M. (2000). General perceived self-efficacy. Retrieved from http://www.fu-berlin.de/gesund/skalen/langu.../hauptteil_general_perceived_self-efficac.htm

Schwarzer, R., \& Scholz, Z. U. (2000). Cross-cultural assessment of resources: The general perceived self-efficacy scale. Paper presented at the First Asian Congress of Health Psychology: Health Psychology and Culture, August 28 - 29, Tokyo, Japan.

Segers, J., Inceoglu, I., Vloeberghs, D., Bartram, D., \& Henderick, E. (2008). Protean and boundaryless careers: A study on potential motivators. Journal of Vocational Behavior, 73, 212-230. http://dx.doi.org/10.1016/j.jvb.2008.05.001

Sharma, H. L., \& Rani, R. (2013). Relationship of Personal Growth Initiative with Self- Efficacy among University Postgraduate Students. Journal of Education and Practice.

Shorey, H. S., Little, T. D., Snyder C. R., Kluck, B., \& Robitschek, C. (2007). Hope and personal growth initiative: a comparison of positive, future oriented constructs. Personality and Individual Differences, 43, 1917-1926. http://dx.doi.org/10.1016/j.paid.2007.06.011

Stajkofic, A. D., \& Luthans, F. (1998). Self-efficacy and work-related performance: A meta-analysis. Psychological Bulletin, 124, 240-261. http://dx.doi.org/10.1037/0033-2909.124.2.240

Sullivan, S. E., \& Arthur, M. B. (2006). The evolution of the boundaryless career concept: Examining physical and psychological mobility. Journal of Vocational Behavior, 69, 19-29. http://dx.doi.org/10.1016/j.jvb.2005.09.001

Sullivan, S. E., Martin, D. F., Carden, W. A., \& Mainiero, L. A. (2003). The road less travelled: How to manage the recycling career stage. Journal of Leadership \& Organizational Studies, 10(2), 34-42. http://dx.doi.org/10.1177/107179190301000204

Turan, S., Valcke, M., Aper, L., Koole, S., \& Derese, A. (2013). Studying self-efficacy beliefs in medical education, Procedia-Social and Behavioural Sciences, 93, 1311-1314. http://dx.doi.org/10.1016/j.sbspro.2013.10.034

Weer, C. H. (2006). The impact of non-work role commitment on employees' career growth prospect. Retrieved from http://idea.library.drexel.edu/bitstream/1860/1165/1/weer_christy.pdf

Weigold, I. K., Porfeli, E. J., \& Weigold, A. (2013). Examining tenets of personal growth initiative using the personal growth initiative scale-II. Psychological Assessment, 25(4), 1396-1403. http://dx.doi.org/10.1037/a0034104

Whiston, S. C., \& Blustein, D. L. (2013). The impact of career interventions: Preparing our citizens for the 21 st century jobs. (Research Report). National Career Development Association (www.ncda.org) and the Society for Vocational Psychology (www.div17.org/vocpsych/). 
Whitaker, A. E., \& Robitschek, C. (2001). Multidimensional family functioning as predictors of personal growth initiative. Journal of Counselling Psychology, 48, 420-427. http://dx.doi.org/10.1037/0022-0167.48.4.420

Williams, T., \& Williams, K. (2010). Self-efficacy and performance in mathematics: Reciprocal determinism in 33 nations. Journal of Educational Psychology, 102(2), 453-466. http://dx.doi.org/10.1037/a0017271

Wright, S. L., Jenkins-Guarnieri, M. A., \& Murdock, J. (2013). Career development among first-year college students, college self-efficacy, student persistence, and academic success. Journal of Career Development, 40(4), 292-310. http://dx.doi.org/10.1177/0894845312455509

$\mathrm{Wu}, \mathrm{W}$. (2002). An empirical study of past performance, goal commitment, computer self-efficacy, computer performance of computer skill learner-an integration of social cognitive theory and goal-setting theory. Retrieved from http://www.ntnu.edu.tw/acad/epub/j47/se471-3.htm

Yakunina, E. S., Weigold, I. K., \& Weigold, A. (2013). Personal growth initiative: Relations with acculturative stress and international student adjustment. International Perspectives in Psychology: Research, Practice, Consultation, 2(1), 62-71.

\section{Copyrights}

Copyright for this article is retained by the author(s), with first publication rights granted to the journal.

This is an open-access article distributed under the terms and conditions of the Creative Commons Attribution license (http://creativecommons.org/licenses/by/3.0/). 